\title{
PENYERAPAN ION Pb(II) MENGGUNAKAN ADSORBEN DARI LIMBAH PADAT LUMPUR AKTIF PENGOLAHAN AIR MINUM
}

\author{
Intan Lestari ${ }^{1}$, Mahra Mahraja ${ }^{1}$, Faizar Farid ${ }^{1}$, Diah Riski Gusti ${ }^{1}$, Edwin Permana ${ }^{2}$ \\ ${ }^{1}$ Program Studi Kimia, Fakultas Sains dan Teknologi \\ ${ }^{2}$ Program Studi Kimia Industri, Fakultas Sains dan Teknologi \\ Universitas Jambi
}

\begin{abstract}
ABSTRAK
Timbal merupakan salah satu polutan yang paling banyak digunakan dalam beberapa kegiatan industri seperti penambangan, peleburan, pemurnian minyak bumi, percetakan, produksi pigmen, dan pembuatan baterai. Permasalahan logam berat dapat ditanggulangi dengan penurunan kadar logam berat menggunakan teknik penyerapan. Salah satu adsorben yang digunakan untuk penyerapan ion $\mathrm{Pb}$ (II) adalah limbah padat lumpur aktif dari pengolahan air minum. Penelitian ini bertujuan untuk menggunakan limbah padat lumpur aktif yang di ambil dari sisa pengolahan air minum PDAM Tirta Mayang Jambi dan diaktifasi menggunakan $\mathrm{KOH}$. Adsorben digunakan untuk penyerapan ion $\mathrm{Pb}(\mathrm{II})$ dengan metoda penyerapan dilakukan secara statis. Adsorben dikarakterisasi menggunakan FTIR, SEM dan XRF. Ion $\mathrm{Pb}(\mathrm{II})$ dalam larutan dianalisis dengan menggunakan metoda Spektrofotometer Serapan Atom (SSA). Parameter penyerapan yang dipelajari adalah $\mathrm{pH}$ diperoleh pada $\mathrm{pH} 5$, massa adsorben 0,2 g, waktu kontak 45 menit dan konsentrasi ion $\mathrm{Pb}(\mathrm{II})$ adalah 300 $\mathrm{mg} / \mathrm{L}$ dengan kapasitas adsorbs $25,42 \mathrm{mg} / \mathrm{g}$.
\end{abstract}

Kata kunci : Lumpur aktif, adsorben, Ion $\mathrm{Pb}(\mathrm{II})$, penyerapan, SSA.

\begin{abstract}
The lead metal is one of the pollutants most widely used in several industrial activities such as mining, smelting, refining petroleum, printing, pigment production, and battery production. Heavy metal problems can be overcome by decreasing heavy metal content using adsorption techniques. One of the adsorbents used for $\mathrm{Pb}$ (II) ion adsorption is avtivated sludge solid waste from drinking water treatment. This study aims using activated sludge solid waste from drinking water treatment Local Water Company Tirta Mayang Jambi and activated using $\mathrm{KOH}$. The adsorbent used for adsorption of $\mathrm{Pb}(\mathrm{II})$ ion by batch technique. Adsorbents are characterized using FTIR. SEM, XRF. $\mathrm{Pb}(\mathrm{II})$ ion in the solution analysis with Adsorption Atomic Spectrophotometer (AAS). The adsorption parameters studied were $\mathrm{pH}$ was $\mathrm{pH} 5$, adsorbent mass was $0.2 \mathrm{~g}$, contact time was 45 minute and concentration of $\mathrm{Pb}(\mathrm{II})$ ion was $300 \mathrm{mg} / \mathrm{L}$ with adsorption capacity was 25.42 $\mathrm{mg} / \mathrm{g}$.
\end{abstract}

Keywords : Activated sludge, adsorbent, $\mathrm{Pb}(\mathrm{II})$ ion, adsorption, AAS.

\section{PENDAHULUAN}

Limbah yang mengandung logam berat termasuk golongan limbah bahan berbahaya dan beracun. Limbah ini merupakan masalah lingkungan yang menjadi perhatian banyak pihak, terutama bagi industri di tanah air. Masalah limbah logam berat sangat serius diperhatikan mengingat dampak yang ditimbulkannya begitu nyata bagi kehidupan makhluk hidup, termasuk manusia. Logam berat dapat menimbulkan gangguan kesehatan bagi manusia (Rachmawati dan Ma'ruf, 2013).

Salah satu logam yang memiliki dampak negatif cukup berbahaya adalah logam timbal $(\mathrm{Pb})$. Timbal merupakan salah

\footnotetext{
* Korespondensi:

Telepon: -

Email: intan.chem15@gmail.com

DOI: https://doi.org/10.35799/cp.13.2.2020.31391
}

satu polutan yang paling banyak digunakan dalam beberapa kegiatan industri seperti penambangan, peleburan, pemurnian minyak bumi, percetakan, produksi pigmen, dan pembuatan baterai. Polusi air yang disebabkan oleh timbal telah menjadi masalah serius bagi kesehatan lingkungan dan masyarakat. Logam timbal bersifat nonbiodegradable dan dapat terakumulasi pada organisme hidup (Ge dkk., 2012; Sud dkk., 2008), oleh karena itu perlu dilakukan penyerapan ion logam timbal dari air limbah sebelum dilepaskan ke lingkungan.

Beberapa metoda konvensional untuk menghilangkan ion $\mathrm{Pb}$ (II) dari fase air meliputi presipitasi, pertukaran ion, penyerapan secara biologis, filtrasi membran, 
elektrokimia, dan adsorpsi (Zhu dkk., 2014). Di antara metoda tersebut adsorpsi adalah metode yang sederhana, efektif, dan ekonomis (Ihsanullah dkk., 2016).

Limbah lumpur adalah produk sampingan dari pengolahan air limbah kota, mengandung beberapa polutan organik, bersifat patogenik, dan mengandung logam berat. Karena tingginya kandungan zat organik, limbah lumpur telah digunakan sebagai bahan baku berbiaya rendah yang cocok untuk pembuatan karbon yang diaktifkan secara pirolisis (Hadi dkk., 2015; Zielin 'ska dan Oleszczuk, 2015). Bahan karbon berpori dapat digunakan untuk menyerap logam berat, antibiotik, pewarna, dan polutan organik lainnya dalam larutan (Ahmed dkk., 2016; Xu dkk., 2015). Konversi limabh lumpur padat menjadi adsorben adalah pilihan yang menjanjikan untuk memanfaatkan limbah lumput padat menjadi adsorben dengan biaya rendah menjadi bahan berguna (Hadi dkk, 2015), serta mengurangi risiko lingkungan yang disebakan oleh keracunan logam. Dalam pembuatan lumpur aktif, aktivasi kimia digunakan dimana aktivator dapat mempengaruhi struktur pori, gugus fungsi dan adsorpsi kinerja logam (Jin dkk., 2014; Trakal dkk., 2014). Aktivator kimia yang biasa digunakan adalah $\mathrm{ZnCl}_{2}$, $\mathrm{NaOH}, \mathrm{KOH}, \mathrm{H}_{2} \mathrm{SO}_{4}$ dan $\mathrm{H}_{3} \mathrm{PO}_{4}$ (Hadi dkk., 2015). Pan dkk (2011) melaporkan bahwa adsorben yang terbuat dari lumpur diaktifasi secara kimia memiliki luas permukaan dan kapasitas adsorpsi yang lebih tinggi untuk polutan dari pada lumpur aktifasi secara biologis. Lumpur aktifasi secara kimia berbeda dari lumpur biologis, yang dihasilkan dari presipitasi kimia air limbah dengan koagulan. Kehadiran koagulan dan produk sampingnya dalam bahan lumpur aktifasi kimia dapat mempengaruhi sifat tekstur dari adsorben lumpur dan hasil penyerapan kontaminan yang dihilangkan (Pan dkk., 2011; Xu dkk., 2015). Apriani dkk (2013) telah melakukan penelitian pembuatan adsorben dari kulit durian yang diaktivasi dengan $\mathrm{KOH}$. Aktivasi ini mampu memperbesar pori dari adsorben dengan konsentrasi $\mathrm{KOH} 25 \%$ dengan ukuran ratarata diameter pori $8,277 \mu \mathrm{m}$ dan mampu menurunkan konsentrasi logam $\mathrm{Fe}$ sebanyak $85,38 \%$.

Hajar dkk (2014) telah memanfaatkan limbah lumpur aktif pengolahan air minum
PDAM Kota Pontianak sebagai adsorben. Lumpur aktif dikarakterisasi menggunakan XRay Flouresence dan ditemukan mengandung $\mathrm{SiO}_{2}$ dan $\mathrm{Al}_{2} \mathrm{O}_{3}$ masing-masing sebesar $49,11 \%$ dan 29,45\%. Adsorben yang diperoleh memiliki daya serap terhadap iod yaitu $363,679 \mathrm{mg} / \mathrm{g}$. Chiang dkk (2012) telah melakukan penelitian menggunakan limbah padat lumpur aktif pengolahan air minum di West Flanders, Belgia untuk penyerapan campuran ion logam $\mathrm{Pb}^{2+}$ dan $\mathrm{Zn}^{2+}$ dengan kapasitas penyerapan maksimum yang diperoleh untuk masing-masing ion logam $\mathrm{Pb}^{2+}$ dan $\mathrm{Zn}^{2+}$ adalah $\quad 0,5 \mathrm{mmol} / \mathrm{g}$ dan 0,19 $\mathrm{mmol} / \mathrm{g}$.

Salmariza (2012) memanfaatkan limbah padat lumpur aktif proses industri karet remah sebagai adsorben menunjukkan bahwa limbah lumpur remah memiliki daya serap yang tinggi, bahkan sampai $100 \%$ dalam menyerap logam $\mathrm{Cr}$ yang terdapat dalam air limbah. Penelitian Kusmaya dan Halim (2004) menggunakan adorben lumpur aktif memberikan hasil yang tinggi dengan persentase efisiensi removal logam berat Cr(III) yaitu 98,26-99,73\%.

Tujuan dari penelitian ini membuat adsorben dari limbah padat lumpur pengolahan air minum PDAM Tirta Mayang Jambi yang diaktifasi secara kimia dengan menggunakan $\mathrm{KOH}$ dan digunakan untuk penyerapan ion $\mathrm{Pb}(\mathrm{II})$. Parameter adsorbsi yang dipelajari adalah variasi $\mathrm{pH}$, waktu kontak dan konsentrasi ion $\mathrm{Pb}(\mathrm{II})$. Adsorben limbah padat lumpur yang di aktifasi $\mathrm{KOH}$ dikarakterisasi menggunakan X-Ray Flourecense (XRF), Fourier Transform Infra Red (FTIR), Scanning Ekectron Microscope (SEM) dan analisis ion $\mathrm{Pb}(\mathrm{II})$ menggunakan SSA.

\section{METODE PENELITIAN}

\section{Preparasi lumpur sisa pengolahan air PDAM}

Sebanyak 150 g sampel limbah padat lumpur dikumpulkan dari limbah pengolahan air minum PDAM Tirta Mayang Jambi, dicuci dengan akuades dan dikeringkan dalam oven pada suhu $110{ }^{\circ} \mathrm{C}$ selama 24 jam. Lumpur padat yang telah kering ditimbang sampai diperoleh berat konstan kemudian diayak dengan ayakan berukuran 170 mesh dan digunakan untuk penelitian selanjutnya. 


\begin{abstract}
Aktivasi lumpur
Sebanyak $100 \mathrm{~g}$ lumpur padat hasil preparasi dimasukan ke dalam gelas piala ukuran $1000 \mathrm{ml}$, ditambahkan larutan $\mathrm{KOH} 2 \mathrm{M}$ dengan perbandingan lumpur dan larutan $\mathrm{KOH}$ yaitu $1: 2$, campuran diaduk menggunakan pengaduk magnet selama 3 jam dengan kecepatan 120 rpm, campuran didiamkan selama 15 menit dan disaring sehingga diperoleh padatan. Padatan dibilas dengan aquades sampai $\mathrm{pH}$ netral dan dikeringkan di dalam oven pada suhu $120{ }^{\circ} \mathrm{C}$ selama 5 jam. Lumpur yang telah diaktivasi digunakan untuk percobaan selanjutnya.
\end{abstract}

\section{Karakterisasi adsorben lumpur aktif}

Identifikasi gugus fungsi pada adsorben lumpur padat setelah diaktivasi dengan $\mathrm{KOH}$ di analisis dengan menggunakan FTIR, morfologi permukaan adsorben dikarakterisasi menggunakan SEM dan komposisi adsorben lumpur aktif sebelum dan sesudah aktivasi ditentukan dengan menggunakan XRF.

\section{Penentuan kondisi optimum adsorpsi ion logam $\mathrm{Pb}(\mathrm{II})$}

Parameter yang dipelajari untuk penentuan kondisi optimum penyerapan adalah pengaruh $\mathrm{pH}$, massa, waktu kontak dan konsentrasi larutan $\mathrm{Pb}(\mathrm{II})$. Sebanyak $20 \mathrm{~mL}$ larutan $\mathrm{Pb}^{2+}$ masing-masing dengan konsentrasi $10 \mathrm{mg} / \mathrm{L}$ disiapkan dan dimasukkan ke dalam 5 buah erlenmeyer $100 \mathrm{~mL}$. pH larutan di atur menjadi $\mathrm{pH} 3$, 4, 5, 6 dan 7 menggunakan larutan $\mathrm{HNO}_{3}$ $0,01 \mathrm{M}$ dan $\mathrm{NaOH} 0,01 \mathrm{M}$, selanjutnya ditambahkan 0,2 $\mathrm{g}$ adsorben lumpur aktif ke dalam masing-masing erlenmeyer yang berisi larutan $\mathrm{Pb}(\mathrm{II})$. Campuran di aduk dengan kecepatan $120 \mathrm{rpm}$ selama 15 menit dan disaring. Filtrat di analisis dengan menggunakan SSA pada panjang gelombang $217 \mathrm{~nm}$. Untuk pengaruh massa adsorben dilakukan dengan memvariasikan massa adsorben dari 0,1 $0,5 \mathrm{~g}$, pengaruh waktu kontak dilakukan dengan memvariasikan waktu kontak dari 15-120 menit dan pengaruh konsentrasi larutan $\mathrm{Pb}(\mathrm{II})$ dilakukan dengan memvariasikan konsentrasi larutan $\mathrm{Pb}$ (II) dari konsentrasi $10-500 \mathrm{mg} / \mathrm{L}$.
Kapasitas penyerapan (Qe) ion logam $\mathrm{Pb}(\mathrm{II})$ dihitung dengan menggunakan persamaan berikut :

$$
\mathrm{Q}_{\mathrm{e}}=\underline{\mathrm{C}_{0}} \underline{\underline{\mathrm{C}}} \underline{\underline{\mathrm{C}}} \mathrm{x} \text { V }
$$

Dengan $\mathrm{Q}_{\mathrm{e}}=$ kapasitas penyerapan $(\mathrm{mg} / \mathrm{g}), \mathrm{C}_{\mathrm{o}}$ $=$ Konsentrasi mula-mula ion $\mathrm{Pb}(\mathrm{II})(\mathrm{mg} / \mathrm{L})$, $\mathrm{C}_{\mathrm{e}}=$ Konsentrasi ion $\mathrm{Pb}(\mathrm{II})$ pada saat kesetimbangan $(\mathrm{mg} / \mathrm{L}), \mathrm{V}=$ volume larutan ion $\mathrm{Pb}(\mathrm{II})(\mathrm{mL})$ dan $\mathrm{m}=$ massa adsorben $(\mathrm{g})$.

\section{HASIL DAN PEMBAHASAN}

\section{Aktivasi lumpur PDAM}

Lumpur padat pengolahan air minum diaktivasi untuk meningkatkan kemampuan dalam proses adsorpsi ion $\mathrm{Pb}$ (II). Proses aktivasi juga berfungsi untuk menghilangkan zat-zat pengotor yang terdapat di dalam lumpur PDAM. Aktivator yang digunakan adalah $\mathrm{KOH}$. $\mathrm{KOH}$ merupakan basa kuat yang mampu menghilangkan zat-zat pengotor dan mampu memperbesar ukuran pori dari adsorben (Apriani dkk., 2013). Penggunaan $\mathrm{KOH}$ akan memberikan endapan silika yang cukup besar. Fadli, dkk (2013) telah melakukan ekstraksi silika dengan menggunakan $\mathrm{KOH}$, endapan $\mathrm{SiO}_{2}$ yang diperoleh sebesar 40,8\%. Proses aktivasi dengan $\mathrm{KOH}$ menghasilkan senyawa mikropori dan mesopori (Zikra dan Yenti, 2016). Hasil limbah lumpur padat yang di aktifasi $\mathrm{KOH}$ dapat dilihat pada Gambar 1 .

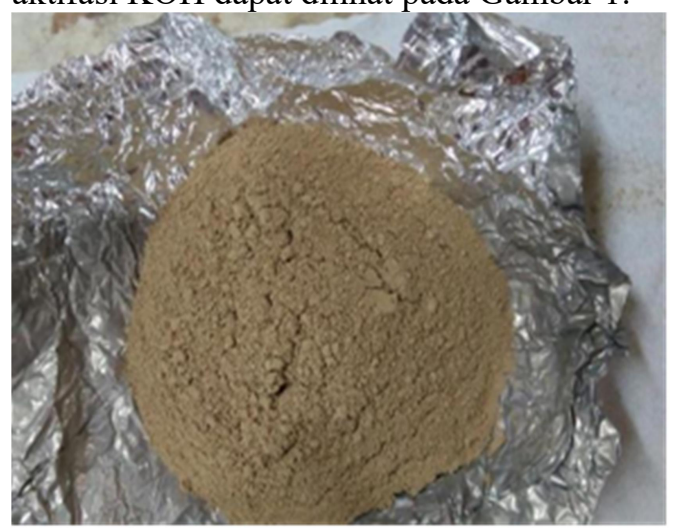

Gambar 1. Serbuk lumpur PDAM aktifasi $\mathrm{KOH}$

\section{Karakterisasi adsorben lumpur aktif}

Spektrum FTIR dari adsorben sebelum dan sesudah penyerapan $\mathrm{Pb}(\mathrm{II})$ ditunjukkan pada Gambar 2. Pita lebar daerah sekitar $3628,28 \mathrm{~cm}^{-1}$ mengindikasikan adanya gugus hidroksil (-OH) dan menyempit setelah penyerapan menjadi $3353,85 \mathrm{~cm}^{-1}$, 
Silverstain, et al (2005) mengungkapkan bahwa pada bilangan gelombang 3550-3200 $\mathrm{cm}^{-1}$ terjadi vibrasi stretching O-H. Pita serapan pada bilangan gelombang 3037,72 $\mathrm{cm}^{-1}$ menunjukan adanya serapan $=\mathrm{C}-\mathrm{H}$, pada bilangan gelombang 1640-1650 $\mathrm{cm}^{-1}$ adanya getaran $\mathrm{C}=\mathrm{C}$ (Martins dkk., 2013), menjadi sempit setelah penyerapan $\mathrm{Pb}(\mathrm{II})$. Pada Gambar 2, puncak baru muncul pada bilangan gelombang 1003,47 $\mathrm{cm}^{-1}$ mengindikasikan adanya vibrasi Si-O, pada $914,6 \mathrm{~cm}^{-1}$ vibrasi tekuk Al-O dan pada $778,85 \mathrm{~cm}^{-1}$ vibrasi tekuk Si-OH. Setelah penyerapan ion $\mathrm{Pb}$ (II) terjadi pergeseran. Pergeseran ini menyatakan bahwa terbentuk komplek langsung antara ion $\mathrm{Pb}(\mathrm{II})$ dan gugus aktif yang ada pada permukaan adsorben. Panda dkk (2011) melaporkan terjadi pergeseran pita bilangan gelombang menjadi lebih rendah disebabkan oleh adsorpsi ion timbal.

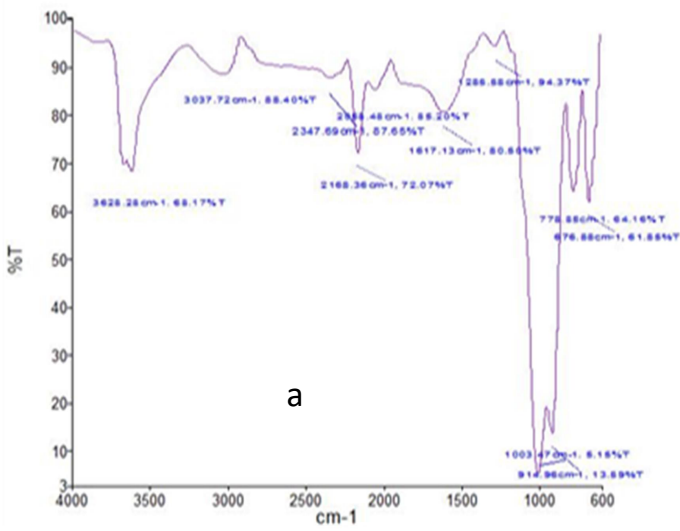

Gambar 2a. Spektra FTIR sebelum penyerapan.

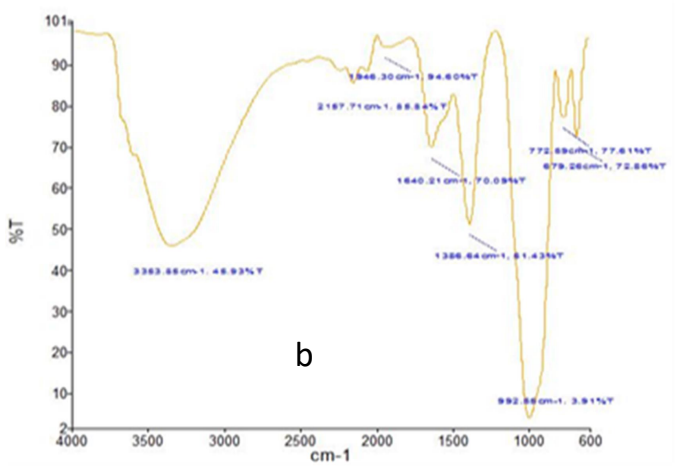

Gambar 2b. Spektra FTIR setelah penyerapan $\mathrm{Pb}(\mathrm{II})$.

Dari spektra FTIR tampak jelas terdapat gugus $-\mathrm{OH}$, menurut Sari (2016) adanya gugus $-\mathrm{OH}$ membantu dalam proses penyerapan dimana ikatan yang terbentuk adalah ikatan kompleks terkoordinasi karena pasangan elektron bebas dari atom $\mathrm{O}$ pada $\mathrm{OH}$ akan menempati orbital kosong yang dimiliki oleh ion $\mathrm{Pb}$ (II). Berdasarkan prinsip Hard and Soft Acid Base (HSAB) ion $\mathrm{Pb}(\mathrm{II})$ adalah kation yang bersifat asam lemah, akan dapat berikatan dengan basa kuat seperti ion hidroksida $\mathrm{OH}^{-}$dan ion karboksilat $\mathrm{CH}_{3} \mathrm{COO}^{-}$ (Sukarta, 2008).

\section{Karakterisasi morfologi permukaan}

Karakterisasi SEM digunakan untuk menganalisis morfologi permukaan pada lumpur PDAM sebelum dan setelah aktivasi. Untuk hasil SEM lumpur yang belum teraktivasi dan setelah teraktivasi dapat dilihat pada Gambar 3. Morfologi permukaan lumpur tidak teraktivasi dan teraktifasi $\mathrm{KOH}$ tidak menunjukkan perubahan yang terlalu signifikan. Hasil morfologi SEM menunjukkan bahwa lumpur yang teraktivasi $\mathrm{KOH}$ memiliki morfologi gumpalan seperti lempengan yang lebih besar. Lempengan yang besar memiliki pori yang lebih banyak, sehingga dapat meningkatkan proses adsorpsi. Hasil SEM setelah proses teraktivasi $\mathrm{KOH}$, struktur pori-pori lumpur tidak terlalu terlihat karena disebabkan oleh beberapa partikel yang menempel pada pori-pori lumpur tersebut. Pada penelitian Mustopa dan Risanti (2013) diperoleh morfologi permukaan lumpur yang tidak teraktivasi dan teraktivasi $\mathrm{KOH}$ memiliki morfologi yang menggumpal (aglomerasi).

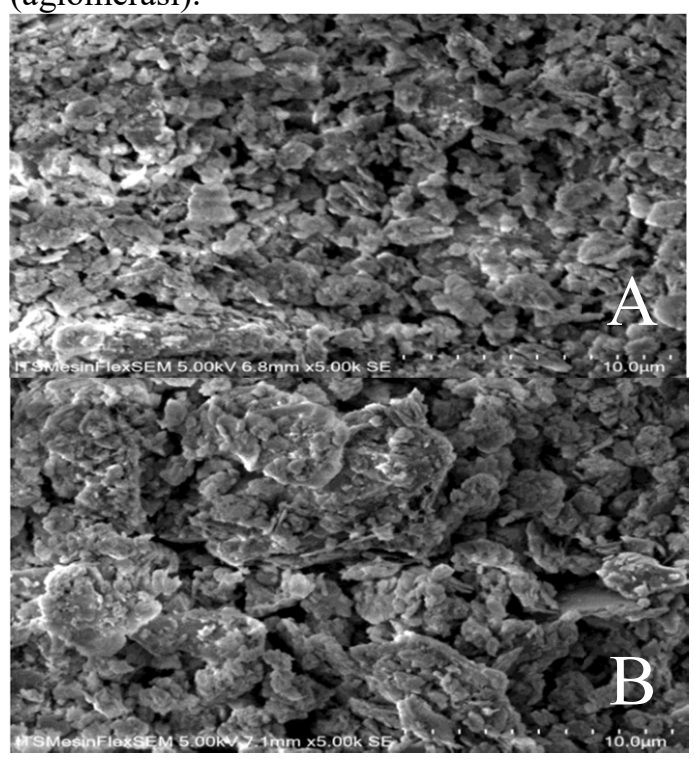

Gambar 3. Struktur morfologi adsorben lumpur teraktifasi $\mathrm{KOH}$ sebelum (A) dan setelah penyerapan $\mathrm{Pb}$ (II) (B). 
Chiang dkk (2012) memperoleh hasil SEM dari lumpur aktif PDAM di West Flanders Belgia memiliki morfologi permukaan yang hampir sama dengan lumpur PDAM Tirta Mayang Kota Jambi. Morfologi permukaan yang dimiliki oleh lumpur PDAM di West Flanders, Belgia berupa gumpalan hanya saja gumpalan tidak menyerupai lempengan. Mustopa dan Risanti (2013) juga memberikan hasil yang sama untuk lumpur lapindo Sidoarjo, dimana aktivator basa yang digunakan dalam proses aktivasi adalah $\mathrm{NaOH}$.

\section{Karakterisasi XRF.}

Analisis unsur- unsur yang terdapat pada adsorben lumpur yang diaktifasi $\mathrm{KOH}$ dilakukan menggunakan XRF dan hasil dapat dilihat pada Tabel 1.

Tabel 1. Hasil Karakterisasi XRF Sebelum Proses Penyerapan Ion Logam Pb(II)

\begin{tabular}{cccccc}
\hline Unsur & Konsentrasi & $\begin{array}{c}\text { Komponen } \\
\text { Geologi }\end{array}$ & Konsentrasi & $\begin{array}{c}\text { Komponen } \\
\text { Oksida }\end{array}$ & Konsentrasi \\
\hline $\mathrm{Al}$ & $25.102 \%$ & $\mathrm{Al}_{2} \mathrm{O}_{3}$ & $28.807 \%$ & $\mathrm{Al}_{2} \mathrm{O}_{3}$ & $28.702 \%$ \\
$\mathrm{Si}$ & $52.636 \%$ & $\mathrm{SiO}_{2}$ & $57.793 \%$ & $\mathrm{SiO}_{2}$ & $57.518 \%$ \\
$\mathrm{P}$ & $0.588 \%$ & $\mathrm{P}_{2} \mathrm{O}_{5}$ & $0.594 \%$ & $\mathrm{P}_{2} \mathrm{O}_{5}$ & $0.591 \%$ \\
$\mathrm{Mg}$ & $1.808 \%$ & $\mathrm{MgO}$ & $2.008 \%$ & $\mathrm{MgO}$ & $2.001 \%$ \\
$\mathrm{Ca}$ & $1.056 \%$ & $\mathrm{CaO}$ & $0.610 \%$ & $\mathrm{CaO}$ & $0.606 \%$ \\
$\mathrm{~K}$ & $3.174 \%$ & $\mathrm{~K}_{2} \mathrm{O}$ & $1.632 \%$ & $\mathrm{~K}_{2} \mathrm{O}$ & $1.622 \%$ \\
$\mathrm{Fe}$ & $12.139 \%$ & $\mathrm{Fe}_{2} \mathrm{O}_{3}$ & $6.612 \%$ & $\mathrm{Fe}_{2} \mathrm{O}_{3}$ & $6.567 \%$ \\
\hline
\end{tabular}

Tabel 2. Hasil Karakterisasi XRF Setelah Proses Penyerapan Ion Logam Pb(II)

\begin{tabular}{cccccc}
\hline Unsur & Konsentrasi & $\begin{array}{c}\text { Komponen } \\
\text { Geologi }\end{array}$ & Konsentrasi & $\begin{array}{c}\text { Komponen } \\
\text { Oksida }\end{array}$ & Konsentrasi \\
\hline $\mathrm{Al}$ & $23.966 \%$ & $\mathrm{Al}_{2} \mathrm{O}_{3}$ & $28.106 \%$ & $\mathrm{Al}_{2} \mathrm{O}_{3}$ & $28.038 \%$ \\
$\mathrm{Si}$ & $54.157 \%$ & $\mathrm{SiO} 2$ & $60.198 \%$ & $\mathrm{SiO}_{2}$ & $60.009 \%$ \\
$\mathrm{P}$ & $0.366 \%$ & $\mathrm{P}_{2} \mathrm{O}_{5}$ & $0.371 \%$ & $\mathrm{P}_{2} \mathrm{O}_{5}$ & $0.369 \%$ \\
$\mathrm{Mg}$ & $0.943 \%$ & $\mathrm{MgO}$ & $1.086 \%$ & $\mathrm{MgO}$ & $1.066 \%$ \\
$\mathrm{Ca}$ & $0.906 \%$ & $\mathrm{CaO}$ & 0.4995 & $\mathrm{CaO}$ & $0.497 \%$ \\
$\mathrm{~K}$ & $9.592 \%$ & $\mathrm{~K} 2 \mathrm{O}$ & $4.852 \%$ & $\mathrm{~K} 2 \mathrm{O}$ & $4.831 \%$ \\
$\mathrm{Fe}$ & $7.004 \%$ & $\mathrm{Fe}_{2} \mathrm{O}_{3}$ & $3.734 \%$ & $\mathrm{Fe}_{2} \mathrm{O}_{3}$ & $3.716 \%$ \\
$\mathrm{~Pb}$ & $0.989 \%$ & $\mathrm{~Pb}$ & $0.340 \%$ & $\mathrm{PbO}$ & $0.364 \%$ \\
\hline
\end{tabular}

Dari Tabel 1 dapat dilihat bahwa sebelum penyerapan ion logam $\mathrm{Pb}$ (II) ditemukan beberapa unsur-unsur yang dominan seperti Al dalam bentuk senyawa $\mathrm{Al}_{2} \mathrm{O}_{3}$ dan $\mathrm{Si}$ dalam bentuk $\mathrm{SiO}_{2}$. Senyawa $\mathrm{Al}_{2} \mathrm{O}_{3}$ dan $\mathrm{SiO}_{2}$ merupakan senyawa yang berperan sangat penting dalam proses penyerapan karena dapat mengikat ion logam $\mathrm{Pb}$ (II). Pada Tabel 1 tidak ada ditemukan ion $\mathrm{Pb}$ (II) dalam limbah padat lumpur aktif. Akan tetapi pada Tabel 2 setelah dilakukan proses penyerapan ion $\mathrm{Pb}(\mathrm{II})$ ditemukan unsur $\mathrm{Pb}$ sebesar $0,989 \%$, hal ini berarti telah terjadi penyerapan ion logam pada permukaan adsorben limbah lumpur aktif. 


\section{Penentuan Kondisi Optimum Adsorpsi Ion Logam Pb(II)}

\section{Pengaruh $\mathrm{pH}$ terhadap penyerapan}

Pengaruh $\mathrm{pH}$ terhadap penyerapan

$\mathrm{Pb}$ (II) dapat dilihat pada Gambar 4. Penyerapan yang baik terjadi pada $\mathrm{pH} 4$ dengan nilai kapasitas penyerapan yaitu 0,987 $\mathrm{mg} / \mathrm{g}$. Pada $\mathrm{pH}$ rendah (1-3) atau $\mathrm{pH}$ asam penyerapan ion logam $\mathrm{Pb}$ (II) relatif kecil. Hal ini dapat disebakan pada kondisi asam, gugus fungsi yang terdapat pada adsorben terprotonasi, sehingga terjadi pengikatan ion hidrogen $\left(\mathrm{H}^{+}\right)$dan ion hidronium $\left(\mathrm{H}_{3} \mathrm{O}^{+}\right)$. Dalam kondisi asam permukaan adsorben bermuatan positif, maka akan terjadi tolakan antara permukaan adsorben dengan ion logam akibatnya adsorpsi rendah. Pada $\mathrm{pH} 4$ adsorpsi relatif tinggi, hal ini dapat terjadi karena kompleks hidrokso logam $\left(\mathrm{MOH}^{+}\right)$ yang terbentuk di dalam larutan lebih banyak, demikian juga permukaan adsorben akan bermuatan negatif dengan melepaskan proton sehingga melalui gaya elekstrostatik akan terjadi tarik menarik yang menyebabkan peningkatan adsorpsi. Reaksi yang terjadi sebagai berikut :

$\mathrm{Pb}^{2+}+2 \mathrm{H}_{2} \mathrm{O} \leftrightarrow\left[\mathrm{Pb}(\mathrm{OH})_{2}\right]^{+}+2 \mathrm{H}^{+}$

Pada $\mathrm{pH} 5$ ke atas adsorpsi mulai menurun, hal ini terjadi karena pada $\mathrm{pH}$ tersebut ion logam $\mathrm{Pb}$ (II) mulai terhidrolisis dan terbentuk spesies $\mathrm{Pb}(\mathrm{OH})_{3}{ }_{3}^{-}$. Pada $\mathrm{pH}$ tinggi permukaan adsorben bermuatan negatif, akibatnya terjadi tolakan antara permukaan adsorben dan spesies ion logam, sehingga adsorpsi menjadi berkurang. Pada $\mathrm{pH}$ netral atau cenderung basa efisiensi adsorpsi dan kapasitas penyerapan cenderung mengalami penurunan, hal ini disebabkan karena $\mathrm{Pb}$ (II) dapat mengalami reaksi hidrolisis dalam larutan sehingga tidak stabil dan menyebabkan kemampuan adsorben limbah lumpur aktif mengalami penurunan untuk menyerap $\mathrm{Pb}(\mathrm{II})$. Pada kondisi $\mathrm{pH}$ basa, ion logam dapat membentuk endapan hidroksida sehingga proses adsorpsi sulit terjadi (Raditya dan Hendiyanto, 2010).

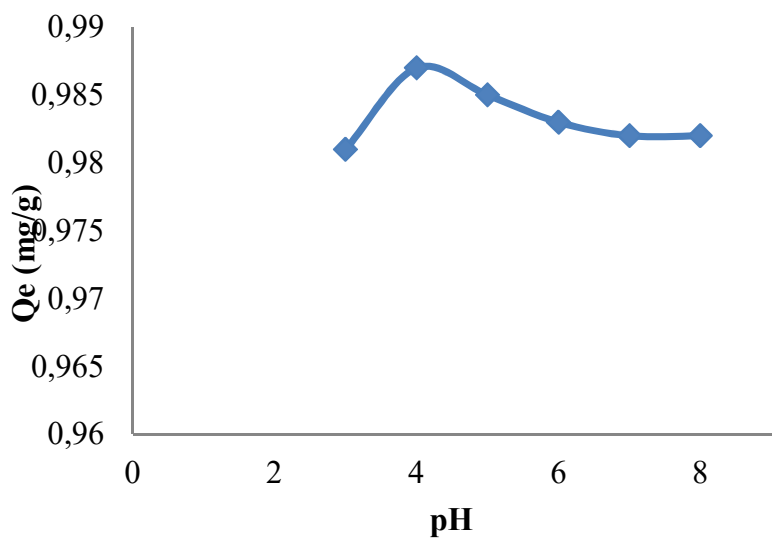

Gambar 4. Pengaruh $\mathrm{pH}$ terhadap kapasitas penyerapan $\mathrm{Pb}$ (II) pada adsorben lumpur aktifasi $\mathrm{KOH}$.

\section{Pengaruh massa}

Pengaruh massa terhadap kapasitas penyerapan dapat dilihat pada Gambar 5 . Semakin banyak adsorben yang digunakan, maka kapasitas peneyerapan semakin menurun. Namun pada efisiensi hasil yang diperoleh tidak memberikan hasil yang linear. Pada Gambar 5 dapat dilihat massa adsorben $0,2 \mathrm{~g}$ memiliki kapasitas penyerapan dan efesiensi yang tinggi dengan nilai berturutturut yaitu $0,969 \mathrm{mg} / \mathrm{g}$. Menurut Nurafriyanti dkk (2017) semakin banyak adsorben yang digunakan maka semakin banyak gugus aktif yang tersedia sehingga pertukaran $\mathrm{H}^{+}$dengan ion logam, tetapi terjadi penurunan penyerapan oleh adsorben karena ion logam dan adsorben telah mencapai titik jenuh sehingga adsorben tidak mampu lagi untuk menyerap ion logam. Peningkatan kapasitas adsorpsi disebabkan oleh jumlah pembukaan situs aktif yang lebih besar sehingga adsorben lebih banyak menjerap adsorbat dan kapasitas adsorpsi akan meningkat sampai tercapainya bobot optimum. Setelah kondisi optimum, tidak tampak terjadi penyerapan yang signifikan. Hal ini disebabkan sudah tidak ada lagi adsorbat yang dijerap sehingga penambahan adsorben sampai kondisi tertentu tidak akan memberi dampak pada peningkatan kapasitas adsorpsi (Maslahat dkk., 2015). 


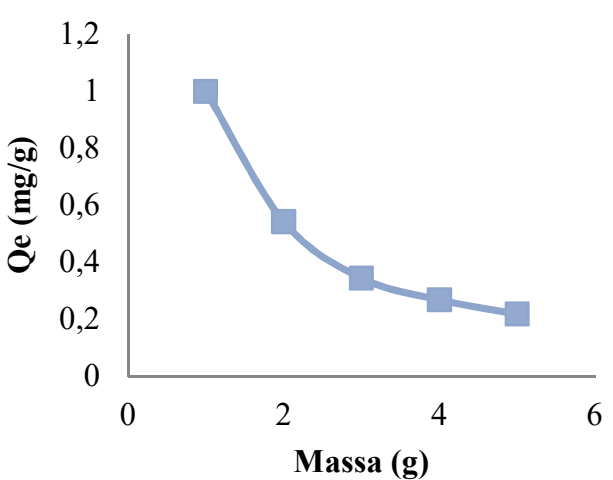

Gambar 5. Pengaruh massa adsorben terhadap kapasitas penyerapan $\mathrm{Pb}(\mathrm{II})$.

\section{Pengaruh waktu kontak}

Pengaruh waktu kontak dapat dilihat pada Gambar 6. Semakin lama waktu kontak semakin banyak logam yang terserap karena semakin banyak kesempatan partikel adsorben untuk bersinggungan dengan logam. Akan tetapi apabila adsorbennya telah jenuh, maka waktu kontak tidak lagi berpengaruh terhadap daya serap. Pada waktu kontak 90 menit terjadi penurunan kapasitas serapan. Hal ini terjadi karena waktu kontak yang terlalu lama menyebabkan terjadinya peristiwa desorpsi adsorbat dari permukaan adsorben disebabkan karena permukaan adsorben telah jenuh. Waktu kontak yang lebih lama memungkinkan proses difusi dan penempelan molekul adsorbat berlangsung lebih baik, namun pada kondisi dinama situs aktif sudah jenuh akan terjadi penurunan kapasitas penyerapan (Salmariza dkk., 2016). Dari hasil analisis yang dilakukan, pengaruh waktu kontak terhadap kapasitas penyerapan memiliki bentuk grafik yang linear. Kapasitas penyerapan semakin besar seiring bertambahnya waktu kontak. Kapasitas adsorpsi terbesar terjadi pada waktu 60 menit, kemudian mengalami penurunan kapasitas penyerapan pada waktu 90 menit. Menurut Maslahat dkk (2015) Penambahan waktu kontak tidak akan memberikan pengaruh yang signifikan terhadap penyerapan $\mathrm{Pb}(\mathrm{II})$ dalam adsorben. Waktu optimum tercapai apabila peningkatan kadar $\mathrm{Pb}(\mathrm{II})$ teradsorpsi mencapai titik maksimalnya, sehingga penambahan waktu kontak tidak akan memberikan pengaruh yang signifikan terhadap pengurangan kadar $\mathrm{Pb}(\mathrm{II})$ dalam sampel. Dalam hal ini terjadi karena $\mathrm{Pb}$ (II) teradsorpsi secara fisik (reversible) yang menyebabkan semakin lamanya waktu kontak akan menyebabkan terlepasnya kembali $\mathrm{Pb}$ (II) ke dalam larutan sampel (Lestari, 2010).

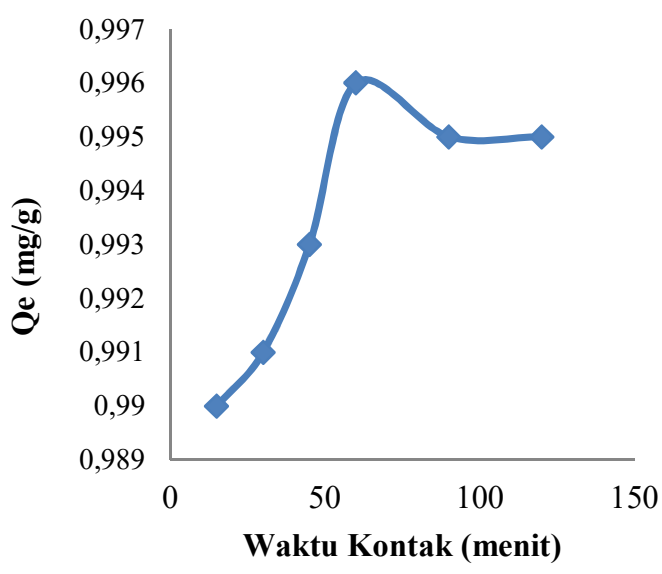

Gambar 6. Pengaruh waktu kontak terhadap kapasitas penyerapan $\mathrm{Pb}(\mathrm{II})$.

\section{Pengaruh konsentrasi larutan}

Pengaruh konsentrasi larutan $\mathrm{Pb}$ (II) terhadap kapasitas penyerapan dapat dilihat pada Gambar 7. Jumlah ion $\mathrm{Pb}$ (II) yang terserap meningkat seiring dengan bertambahnya konsentrasi larutan $\mathrm{Pb}$ (II) yang dikontakkan dengan adsorben lumpur. Pada konsentrasi rendah yaitu $10 \mathrm{mg} / \mathrm{L}$ kapasitas penyerapan yang diperoleh sebesar 0,995 $\mathrm{mg} / \mathrm{g}$ kemudian mengalami peningkaan seiring dengan bertambahnya konsentrasi larutan $\mathrm{Pb}(\mathrm{II})$ hingga mencapai kondisi optimum pada konsentrasi $300 \mathrm{mg} / \mathrm{L}$ dengan kapasitas penyerapan $25,42 \mathrm{mg} / \mathrm{g}$. Hal ini sesuai dengan penelitian Venugopal dan Mohanty (2011) yang menyatakan bahwa dengan meningkatnya konsentrasi ion logam efisiensi penyerapan semakin berkurang, dikarenakan kemampuan menyerap adsorben terhadap ion logam sudah maksimum dimana penurunan efisiensi penyerapan pada konsentrasi tinggi terjadi karena jumlah ion logam dalam larutan tidak sebanding dengan jumlah partikel adsorben yang tersedia sehingga adsorben akan mencapai titik jenuh dan efisiensi penyerapan akan berkurang. Konsentrasi ion logam sangat erat hubungannya dengan jumlah sisi aktif yang terdapat pada permukaan adsorben, yang mampu mengikat logam tersebut. Bila jumlah sisi aktif cukup besar dibanding jumlah ion logam maka kapasitas penyerapan akan tinggi. Namun pada kondisi tertentu kapasitas 
penyerapan akan konstan bahkan terjadi penurunan karena telah terjadi kejenuhan pada adsorben. Pada konsentrasi yang lebih tinggi, jumlah ion yang tersedia untuk berikatan di daerah ikatan permukaan berlebih dan gaya dorong dari ion logam semakin kuat, dengan demikian terjadi peningkatan adsorpsi (Chaidir dkk., 2015). Konsentrasi ion logam berhubungan dengan banyaknya ion logam yang dapat berinteraksi dengan sisi aktif adsorben. Sehingga semakin banyak ion logam dalam larutan maka semakin banyak kemungkinan terjadinya interaksi dengan sisi aktif adsorben sehingga kapasitas penyerapan meningkat (Bhernama, 2017).

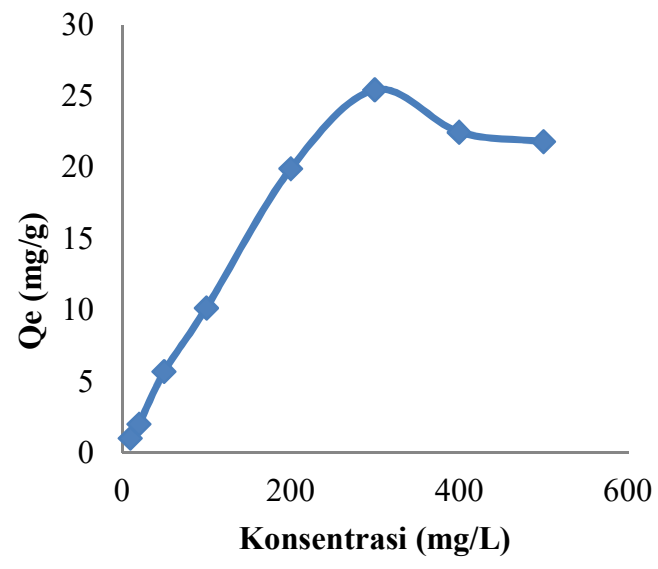

Gambar 7. Pengaruh kosentrasi terhadap kapasitas penyerapan $\mathrm{Pb}(\mathrm{II})$.

\section{KESIMPULAN}

Limbah lumpur aktif pengolahan air minum PDAM Tirta Mayang Jambi memiliki potensi untuk dijadikan sebagai adsorben ion logam $\mathrm{Pb}(\mathrm{II})$ dengan adanya kandungan utama silika dan alumina yang merupakan situs aktif dalam pembuatan adsorben, dan munculnya gugus hidroksil $(\mathrm{O}-\mathrm{H})$ setelah dilakukannya proses aktivasi yang mampu meningkatkan kinerja adsorben dalam proses penyerapan ion logam $\mathrm{Pb}(\mathrm{II})$. Adsorben dari limbah lumpur aktif pengolahan air minum PDAM Tirta Mayang Jambi memiliki morfologi permukaan yang menggumpal (aglomerasi), dimana lumpur yang teraktivasi $\mathrm{KOH}$ memiliki morfologi permukaan seperti lempengan yang lebih besar dibandingkan dengan lumpur sebelum teraktivasi $\mathrm{KOH}$. Penyerapan optimum ion logam $\mathrm{Pb}$ (II)

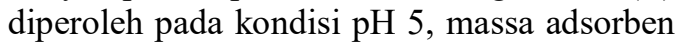

0,2 g, waktu kontak 60 menit dan konsentrasi larutan $\mathrm{Pb}$ (II) adalah $300 \mathrm{mg} / \mathrm{L}$ dengan kapasitas penyerapan sebesar $25,420 \mathrm{mg} / \mathrm{g}$.

\section{DAFTAR PUSTAKA}

Ahmed, M.B., Zhou, J.L., Ngo, H.H. \& Guo, W. 2016. Insight into biochar properties and its cost analysis. Biomass Bioenergy. 84, 76-86.

Apriani, R., Faryuni, I.D. \& Wahyuni, D. 2013. Pengaruh konsentrasi aktivator kalium hidroksida $(\mathrm{KOH})$ terhadap kualitas karbon aktif kulit durian sebagai adsorben logam $\mathrm{Fe}$ pada air gambut. Prisma Fisika. 1(2), 82-86.

Chiang, Y. W., Santos, R.M., Ghyselbrecht, K., Cappuyns, V., Martens, J.A., Swennen, R. \& Meesschaert, B. 2012. Adsorption of multi-heavy metals onto water treatment residuals: sorption capacities and applications. Journal of Chemical Engineering. 200, 405-415.

Chaidir, Z., Hasanah, Q. \& Zein, R. 2015. Penyerapan ion logam $\mathrm{Cr}$ (III) dalam larutan menggunakan kulit buah jengkol (Pithecellobium jiringa (Jack) Prain.). Jurnal Riset Kimia. 8(2), 24768960.

Ge, F., Li, M.M., Ye, H. \& Zhao, B. 2012. Effective removal of heavy metal ions $\mathrm{Cd}^{2+}, \mathrm{Zn}^{2+}, \mathrm{Pb}^{2+}, \mathrm{Cu}^{2+}$ from aqueous solution by polymer-modified magnetic nanoparticles. Journal of Hazardous Matter. 211-212, 366-372.

Hadi, P., Xu, M., Ning, H. \& Lin, C.S.K. 2015. A critical review on preparation, characterization and utilization of sludgederived activated carbons for wastewater treatment. Chemical Engineering Journal. 260, 895-906.

Hajar, S., Wahyuni, N. \& Destiarti, L. 2014. Karakterisasi Zeolit A sintetis dari lumpur PDAM Kota Pontianak dan Alumina. Jurnal Kimia Khatulistiwa. 3(1), 12-16.

Ihsanullah., Patel, F., Khraisheh, M., Atieh, M.A. \& Laoui T. 2017. Novel aluminum oxide-impregnated carbon nanotube membrane for the removal of cadmium from aqueous solution. Materials. 10(10), 1144-1158.

Jin, H., Capareda, S., Chang, Z., Gao, J., Xu, Y. \& Zhang, J. 2014. Biochar pyrolytically produced from municipal 
solid wastes for aqueous $\mathrm{As}(\mathrm{V})$ removal: adsorption property and its improvement with $\mathrm{KOH}$ activation. Bioresource Technology. 169, 622629.

Kusmaya, M., Setiadi T.J. \& Halim, M.B. 2013. Adsorpsi Kadmium(II) dan Kromium(III) dalam air oleh lumpur aktif. Reaktor. 7(2), 77-83.

Lestari, S. 2010. Pengaruh berat dan waktu kontak untuk adsorpsi Timbal(II) oleh adsorben dari kulit batang jambu biji (Psidium guajava L.). Jurnal Kimia Mulawarman. 8(1), 7-10.

Maslahat, M., Taufiq, A. \& Subagja, P.W. 2015. Pemanfaatan limbah cangkang telur sebagai adsorben untuk adsorpsi logam $\mathrm{Pb}$ dan Cd. Jurnal Sains Natural Universitas Nusa Bangsa. 5(1), 92-100.

Martins, A.E., Pereira, M.S., Jorgetto, A.O., Martines, M.A.U., Silva, R.I.V., Saeki, M.J. \& Castro, G.R. 2013. The reactive surface of Castor leaf (Ricinus communis $L$ ) powder as a green adsorbent for the removal of heavy metals from natural river water. Appl. Surf. Sci. 276, 24-30.

Mustopa, R.S. \& Risanti, D.D. 2013. Karakterisasi sifat fisis lumpur panas sidoarjo dengan aktivasi kimia dan fisika. Jurnal Teknik Pomits. 2(2), 256261.

Nurafriyanti., Prihatini, N.S. \& Syauqiah, I. 2017. Pengaruh variasi $\mathrm{pH}$ dan berat adsorben dalam pengurangan konsentrasi $\mathrm{Cr}$ total pada limbah artifisial menggunakan adsorben ampas daun teh. Jurnal Teknik Lingkungan. $3(1), 56-65$.

Pan, Z., Tian, J., Xu, G., Li, J. \& Li, G. 2011. Characteristics of adsorbents made from biological, chemical and hybrid sludges and their effect on organics removal in wastewater treatment. Water Resource. 45, 819827.

Rachmawati, R. \& Ma"ruf, W.F. 2013. Pengaruh lama perebusan kerang darah (Anadara granosa) dengan arang aktif terhadap pengurangan kadar logam kadmium dan kadar logam timbal. Jurnal Pengolahan dan Bioteknologi Hasil Perikanan. 2(3), 41-50.

Raditya, B.C. \& Hendiyanto, O.C. 2010. Pemanfaatan kulit durian sebagai adsorben logam berat $\mathrm{Pb}$ pada limbah cair elektroplating. Jurnal Ilmiah Teknik Lingkungan. Vol 8(1), 10-18.

Salmariza, S., Mardiati, M., Mawardi, M., Sofyan, S., Ardinal, A. \& Purnomo, Y. 2016. Adsorbsi ion $\mathrm{Cr}(\mathrm{VI})$ menggunakan adsorben dari limbah padat lumpur aktif industri crumb rubber. Jurnal Litbang Industri. 6(2), 135-145.

Silverstain, R. M., Webster, F.X. \& Kiemle, D.J. 2005. Identification of organic compounds. New York: John Wiley \& Sons, Inc.

.Sud, D., Mahajan, G., Kaur, M.P. 2008. Agricultural waste material as potential adsorbent for sequestering heavy metal ions from aqueous solutions - a review. Bioresource Technology. 99, 60176027.

Trakal, L., Sigut, R., Sillerova, H., Faturikova, D. \& Komarek, M. 2014. Copper removal from aqueous solution using biochar: effect of chemical activation. Arabian Journal of Chemistry. 7, 43-52.

Venugopal, V. \& Mohanty, K. 2011. Biosorptive uptake of $\mathrm{Cr}(\mathrm{VI})$ from aqueous solutions by Parthenium hysterophorus weed: Equilibrium, Kinetics and Thermodynamic Studies. Chemical Engineering Journal. 174(1), 151-158.

Xu, G., Yang, X., Spinosa, L. 2015. Development of sludge-based adsorbents: preparation, characterization, utilization and its feasibility assessment. Journal of Environment Management. 151, 221232.

Zielinska, A., Oleszczuk, P., 2015. Evaluation of sewage sludge and slow pyrolyzed sewage sludge-derived biochar for adsorption of phenanthrene and pyrene. Bioresource Technology. 192, 618626.

Zikra, N. R. Y., Chairul dan Yenti, S.R. 2016. Adsorpsi ion logam $\mathrm{Pb}$ dengan menggunakan karbon aktif kulit durian yang teraktivasi. Jom FTEKNIK. 3(1), $1-8$. 